\title{
Protective role of the calcium channel blocker amlodipine against mitochondrial injury in ischemia and reperfusion injury of rat liver
}

\author{
CHATTOPADHYAY PRONOBESH ${ }^{1,2}$ \\ AHER VAIBHAV DAGAGI ${ }^{1}$ \\ CHAUDHURY PALLAB ${ }^{3}$ \\ WAHI ARUN KUMAR ${ }^{1}$ \\ ${ }^{1}$ Cellular and Microbiology Laboratory \\ College of Pharmacy, IFTM \\ Moradabad-244001, India \\ ${ }^{2}$ Birla Institute of Technology and \\ Sciences, Pilani, India \\ ${ }^{3}$ National Biotechnology Center, Indian \\ Veterinary Research Institute, Izatnagar \\ India
}

Accepted August 19, 2008

\begin{abstract}
$\mathrm{Ca}^{2+}$ accumulation and $\mathrm{Ca}^{2+}$ overloading in mitochondria are responsible for the cell abnormality associated with ischemia and reperfusion injury. The present study was aimed at evaluating the efficacy of the $\mathrm{Ca}^{2+}$ channel blocker amlodipine on the mitochondrial $\mathrm{Ca}^{2+}$ accumulation, mitochondrial antioxidant status and mitochondrial respiratory enzymes in ischemia and reperfusion (I/R) induced liver injury. I/ $R$ injury induced mitochondrial damage in rats was assessed in terms of the decrease in activities $(p<0.05)$ of respiratory marker enzymes (malate dehydrogenase, succinate dehydrogenase and NADH dehydrogenase), mitochondrial antioxidant enzymes (glutathione, superoxide dismutase, catalase), and significant increase $(p<0.05)$ in the level of lipid peroxidation (LPO) and $\mathrm{Ca}^{2+}$ content.

Mitochondrial damage was confirmed by transmission electron microscopic (TEM) examination. Pretreatment with amlodipine effectively counteracted the alteration in mitochondrial enzymes induced by ischemia-reperfusion liver damage. TEM study confirms the restoration of cellular normalcy and the cytoprotective role of amlodipine against I/R induced hepatic injury. On the basis of our findings it may be concluded that amlodipine not only possesses $\mathrm{Ca}^{2+}$ channel antagonist properties but it may also reduce the extent of mitochondrial damage by its antioxidant activity.
\end{abstract}

Keywords: calcium channel blocker, amlodipine, ischemia and reperfusion injury, mitochondrial injury

Mitochondria are the principal targets in the development of ischemia-reperfusion (I/R) induced hepatic injury $(1,2)$. Increased production of superoxide radicals at the level of the mitochondrial respiratory chain is allegedly a major participant in I/R injury (2). Oxidant stress induced cell killing involves oxidation of pyridine nucleotides, accu-

\footnotetext{
*Correspondence, e-mail: chatto_pronobesh@rediffmail.com
} 
C. Pronobesh et al.: Protective role of the calcium channel blocker amlodipine against mitochondrial injury in ischemia and reperfusion injury of rat liver, Acta Pharm. 58 (2008) 421-428.

mulation of calcium ions in mitochondria, and superoxide formation by mitochondria, ultimately leading to formation of membrane permeability transition pores and breakdown of the mitochondrial membrane potential (3), alteration of mitochondrial enzymes activity, intracellular $\mathrm{Ca}^{2+}$ accumulation and $\mathrm{Ca}^{2+}$ overloading, contributing to irreversible cell damage (4). Ischemia is associated with impaired calcium homeostasis. Ischemic tissue injury causes an increase in free intracellular calcium that leads to diminished recovery of the dilation function after ischemia (vasoconstriction), compromised membrane integrity and decreasing reserves of cellular adenosine triphosphate. Amlodipine is a second-generation dihydropyridine calcium channel blocker shown to have a gradual onset and sustained duration of action because of the selectivity of dihydropyridines for the vascular smooth muscle (5). The pharmacokinetic profile such as that of amlodipine may prove to be valuable in protection from the ischemica and reperfused injuries. A single intravenous dose of $10 \mathrm{mg}$ amlodipine resulted in absolute bioavailability of $64 \%$ and a calculated half-life of 34 hours (6). The present study evaluates the potential effect of the calcium antagonist amlodipine on hepatic mitochondrial marker enzymes, antioxidant and mitochondrial structure in I/R induced hepatotoxicity.

\section{EXPERIMENTAL}

Collagenase and bovine serum albumin (BSA) were purchased from Hymedia (India). Other chemicals were obtained from Sigma (USA).

\section{Experimental design}

Male Wistar rats weighing 200 to $250 \mathrm{~g}$ were purchased from Laboratory Animal Resources, Indian Veterinary Research Institute, Izzatnagar, UP, India. Animals were kept in temperature-controlled rooms at the animal house, College of Pharmacy, IFTM, Moradabad, UP India, with $12 \mathrm{~h}$ alternating light and dark cycles and were given adequate nutrition and water ad libitum. All experimental protocols using animals were performed according to the "Principles of Laboratory Animal Care (NIH publication 85-23, revised 1985). Experimental protocols were reviewed and approved by the institutional Ethical Committee. Eighteen Wistar rats were divided into a control group (I) $(n=6)$, ischemia and reperfusion group (II) $(n=6)$, and amlodipine pre-treated group (1 $\mathrm{mg} \mathrm{kg}^{-1}$ body mass daily by oral route for 7 days before induced ischemia-reperfusion maneuver) (III) $(n=6)$. Ischemia and reperfusion injury was produced as per the procedure described by Hayashi et al. (7). In short, after the induction of anesthesia (urethane $10 \mathrm{mg}$ $\mathrm{kg}^{-1}$ body mass daily by i.p.), the liver of each animal was exposed through a midline laparotomy. Clamping the left branches of the portal vein and the hepatic artery for 60 min produced complete ischemia of the median and left hepatic lobes. The right hepatic lobe was perfused to prevent intestinal congestion. After the period of ischemia, the ligatures around the left branches of the portal vein and hepatic artery were removed. The wound was closed with 3-0 silk. Sham-operated animals were similarly prepared except that no ligature was placed to obstruct the blood flow to the left and median hepatic lobes. Instead, the blood flow to the right lobe of the liver was occluded. After $3 \mathrm{~h}$ reperfusion, rats were euthanized by diethyl ether (S.D. Fine Chemicals Ltd., India) and blood and tissue samples were collected, as described below. 
C. Pronobesh et al.: Protective role of the calcium channel blocker amlodipine against mitochondrial injury in ischemia and reperfusion injury of rat liver, Acta Pharm. 58 (2008) 421-428.

\section{Peripheral tissue procurement}

A portion of ischemic and non-ischemic liver lobes were fixed in buffered $10 \%$ formalin and Karnovsky's solution (2.5\% glutaraldehyde and 2\% formaldehyde in $0.2 \mathrm{~mol}$ $\mathrm{L}^{-1}$ phosphate buffer) for histopathology and TEM studies. Another portion of ischemic and non-ischemic liver lobes were snap frozen in liquid nitrogen and stored for 3 days at $-70{ }^{\circ} \mathrm{C}$ for mitochondria isolation.

\section{Isolation of mitochondria}

The liver mitochondria were isolated by the method of Johnson and Lardy (8). A portion of liver tissue was weighted and homogenized with $0.35 \mathrm{~mol} \mathrm{~L}^{-1}$ sucrose buffer at $4{ }^{\circ} \mathrm{C}$ and centrifuged at $10,000 \times g$ for 5 minutes. The resultant mitochondrial pellet was then resuspended in $0.25 \mathrm{~mol} \mathrm{~L}^{-1}$ sucrose solution containing $10 \mathrm{mmol} \mathrm{L}^{-1}$ Tris- $\mathrm{HCl}(\mathrm{pH}$ 7.4) and $1 \mathrm{mmol} \mathrm{L}^{-1}$ EDTA up to a final volume of $2 \mathrm{~mL}$. Mitochondrial integrity of the hepatocytes was measured by reduction of mitochondrial enzyme succinate dehydrogenase using the 3-(4,5-dimethylthiazolyl)-2,5-diphenyltetrazolium bromide (MTT) assay as described by Barltrop et al. (9).

\section{Assay of enzymes}

The mitochondrial respiratory marker enzymes such as malate dehydrogenase (MDH), succinate dehydrogenase (SDH), NADH dehydrogenase and mitochondrial antioxidants such as glutathione-S-transferase (GST), superoxide dismutase (SOD), catalase (CAT) and mitochondrial lipid peroxides (LPO) were determined as described previously by Mehler et al. (10), Slater and Bonne (11), Minakami et al. (12), Habig et al. (13), Hodgson and Fridovich (14), Takahara et al. (15) and Ohkawa et al. (16), respectively. Mitochondrial calcium was estimated by using the diagnostic kit (Quiligens Diagnostics, India) according to manufacturer's guidelines.

\section{Transmission electron microscopy (TEM) of liver tissue}

Liver tissue was fixed in Karnovsky's solution $\mathrm{pH} 7.4$ for $4 \mathrm{~h}$ at $4{ }^{\circ} \mathrm{C}$. After fixation and an overnight wash in sodium cacodylate buffer at $4{ }^{\circ} \mathrm{C}$, the specimens were postfixed with $1 \%$ osmium tetroxide in $0.1 \mathrm{~mol} \mathrm{~L}^{-1}$ phosphate buffer (pH 7.4), dehydrated in ethanol and then embedded in Araldite resin (Ducupan, Fluka BioChemika, USA). Semi-thin sections $(1 \mu \mathrm{m})$ were cut for optical microscopy. Ultra-thin sections (40-60 nm) were placed on copper mesh grids $(200 \mathrm{~nm})$ and double-stained with uranyl acetate and lead citrate. Sections were examined using a transmission electron microscope (Moragagni 268 $\mathrm{D}$, The Netherlands) and photomicrographs were taken.

\section{Statistical analysis}

All values were expressed as mean $\pm \mathrm{SD}$. Differences in mean values were compared by one-way ANOVA and Student-Newman-Keul (SNK) test. 
C. Pronobesh et al.: Protective role of the calcium channel blocker amlodipine against mitochondrial injury in ischemia and reperfusion injury of rat liver, Acta Pharm. 58 (2008) 421-428.

\section{RESULTS AND DISCUSSION}

The activities of mitochondrial respiratory, viz. malate dehydrogenase (MDH), succinate dehydrogenase (SDH) and NADH dehydrogenase (NADH), marker enzymes were significantly decreased $(p<0.05)$ in the I/R liver injured group of rats compared to the control group (Table I). Pretreatment with amlodipine (group III) reverted the altered activities of these enzymes to near control levels when compared to the sham-operated control group (Table I).

The activity of mitochondrial antioxidant enzymes, viz. glutathione-S-transferase (GST), superoxide dismutase (SOD), catalase (CAT), was significantly $(p<0.05)$ decreased while $\mathrm{Ca}^{2+}$ content and lipid peroxides (LPO) activity was increased significantly $(p<$ 0.05 ) in the I/R injured group of rats compared to the control group (Table II). Activities of these enzymes in mitochondria were almost completely reversed in the amlodipine pretreated group of rats (Table II). Pretreatment with amlodipine also prevented lipid peroxidation compared to the I/R liver injured group of animals.

Table. I. Activities of mitochondrial and respiratory enzymes in the liver of control and experimental groups of rats

\begin{tabular}{lccc}
\hline Group & MDH $^{\mathrm{a}}$ & $\mathrm{SDH}^{\mathrm{b}}$ & NADH dehydrogenase $^{\mathrm{c}}$ \\
\hline Control & $293.12 \pm 25.34$ & $201.40 \pm 17.65$ & $124.36 \pm 19.65$ \\
I/R Injury & $187.25 \pm 33.51^{\mathrm{d}}$ & $112.87 \pm 13.46^{\mathrm{d}}$ & $85.63 \pm 5.61^{\mathrm{f}}$ \\
Amlodipine + I/R injury & $249.70 \pm 27.18^{\mathrm{e}}$ & $182.32 \pm 24.50^{\mathrm{e}}$ & $108.44 \pm 17.49 \mathrm{~g}$ \\
\hline
\end{tabular}

Results are expressed as mean $\pm S D(n=6)$.

a Expressed as nmol of MDH oxidized per min per mg protein.

${ }^{b}$ Expressed as nmol of succinate oxidized per min per $\mathrm{mg}$ protein.

c Expressed as nmol NADH oxidized per min per mg protein.

Significantly different from control group ( $\left.{ }^{\mathrm{d}} p<0.05,{ }^{\mathrm{f}} p<0.01\right)$.

Significantly different from I/R injury group (e $p<0.05, \mathrm{~g} p<0.01$ ).

Table II. Activities of mitochondrial antioxidant enzymes, $\mathrm{Ca}^{+2}$ content and LPO in the liver of control and experimental groups of rats

\begin{tabular}{lccccc}
\hline Group & GST $^{\mathrm{a}}$ & SOD $^{\mathrm{b}}$ & CAT $^{\mathrm{c}}$ & LPO $^{\mathrm{d}}$ & Ca $^{2+\mathrm{e}}$ \\
\hline Control & $64.37 \pm 5.90$ & $15.41 \pm 1.34$ & $1.32 \pm 0.19$ & $4.10 \pm 0.60$ & $7.11 \pm 0.39$ \\
I/R Injury & $40.29 \pm 4.87^{\mathrm{f}}$ & $4.98 \pm 0.91^{\mathrm{h}}$ & $0.94 \pm 0.08^{\mathrm{h}}$ & $7.25 \pm 0.33^{\mathrm{f}}$ & $12.36 \pm 1.54^{\mathrm{f}}$ \\
Amlodipine + I/R injury & $60.87 \pm 5.19 \mathrm{~g}$ & $13.22 \pm 1.47^{\mathrm{i}}$ & $1.30 \pm 0.46^{\mathrm{g}}$ & $3.49 \pm 0.47^{\mathrm{i}}$ & $8.70 \pm 1.22^{\mathrm{i}}$ \\
\hline
\end{tabular}

Results are expressed as mean \pm SD $(n=6)$.

a Expressed as nmol of 1-chloro 2,4-dinitrobenzene (CDNB) oxidized per min per $100 \mathrm{mg}$ protein.

$\mathrm{b}$ Expressed as units per min per $100 \mathrm{mg}$ protein.

c Expressed as nmol of $\mathrm{H}_{2} \mathrm{O}_{2}$ decomposed per min per mg protein.

d Expressed as nmol of MDA per mg of protein.

e Expressed as nmol per mg of protein.

Significantly different ( ${ }^{\mathrm{f}} p<0.05, \mathrm{~h} p<0.01$ ) from control group.

Significantly different ( $\left.\mathrm{g} p<0.05,{ }^{\mathrm{i}} p<0.01\right)$ from I/R injury group. 
Transmission electron microscopy (TEM) studies showed that the I/R injured rats mitochondria of hepatocytes were severely swollen with less quantity and cristae. Pretreatment with amlodipine showed improvement in cytoplasmic changes as well as the fine ultra structure of the mitochondria similarly to the control liver section (Fig. 1).

In the present study, ischemia and reperfusion injury caused severe mitochondrial degeneration leading to the tricarboxyl acid (TCA) cycles marker enzymes (MDH, SDH) which were observed in I/R injured rats. The impaired mitochondrial function, which may contribute to the pathogenesis of I/R induced hepatotoxicity, might be a reason for activation of Kupfer cells leading to generation of reactive oxygen species (ROS).

The activity of the respiratory marker NADH dehydrogenase was lowered in I/R rats. This could be due to enhanced phospholipids degradation and participation of ROS in the mitochondrial electron transfer system. Pretreatment with amlodipine reduced the extent of mitochondrial damage and reversed the activities of TCA cycle and respiratory marker enzymes towards normalcy. The enhanced oxidative stress and mitochondrial calcium overload have been taken to be responsible for mitochondrial dysfunction (17). We observed an increase in the level of calcium in the mitochondria in I/ $R$ induced hepatocytes. Pretreatment with amlodipine prevented the increase in mitochondrial $\mathrm{Ca}^{2+}$ concentration, thereby restoring the mitochondrial function.

In the cellular defence system, GSH (reduced glutathione) plays an important protective role, as an intracellular free radical scavenger, by conjugation with metabolites, and also protects the mitochondrial membrane from the damaging action of LPO (18). Low level of GSH was observed during increased oxidative stress caused by I/R. Cellular GSH depletion is closely related to the lipid peroxidation and disturbance of $\mathrm{Ca}^{2+}$ influx induced by oxidative injury (19). This observation supports our findings where we observed a decline in GST levels in I/R injured rats. Pretreatment with amlodipine in
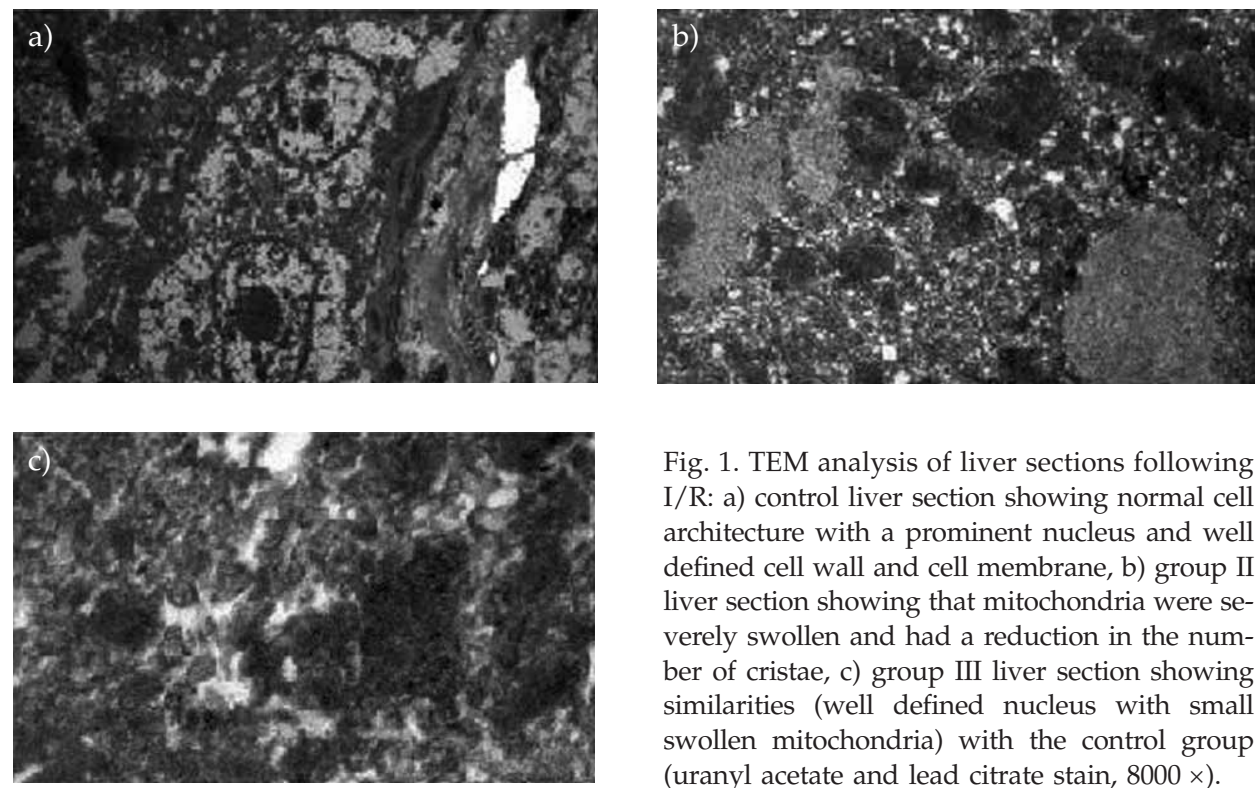

Fig. 1. TEM analysis of liver sections following I/R: a) control liver section showing normal cell architecture with a prominent nucleus and well defined cell wall and cell membrane, b) group II liver section showing that mitochondria were severely swollen and had a reduction in the number of cristae, c) group III liver section showing similarities (well defined nucleus with small swollen mitochondria) with the control group (uranyl acetate and lead citrate stain, $8000 \times$ ). 
C. Pronobesh et al.: Protective role of the calcium channel blocker amlodipine against mitochondrial injury in ischemia and reperfusion injury of rat liver, Acta Pharm. 58 (2008) 421-428.

$\mathrm{I} / \mathrm{R}$ rats maintained the concentration of GSH at near normal levels, which prevented cell disruption, probably by decreasing the $\mathrm{Ca}^{2+}$ influx.

Major antioxidants like SOD, CAT and GST are important for cellular protection due to their ability to detoxify free radicals such as ROS. A number of studies have reported diverse results for the changes of these antioxidant enzyme activities in I/R induced hepatic injury (20). Accentuated mitochondrial lipid peroxidation, accompanied by a deteriorating mitochondrial antioxidant status is evident in $\mathrm{I} / \mathrm{R}$ injured rats. The rise in the activities of mitochondrial antioxidant enzymes in amlodipine pretreated group highlights the protective role of amlodipine in combating the oxidative insult. Lipid peroxidation is one of the major outcomes of free radical-mediated tissue injury and is an indicator of oxidative damage by a series of chain reactions. Increased level of MDA, the end product of LPO, was observed in I/R injured rats. Mitochondrial lipid peroxidation was significantly $(p<0.05)$ lowered in the amlodipine pretreated group compared to the I/R injured group. Our results are in concord with the earlier work done by Wang et al. (21), where it was reported that amlodipine regulates membrane fluidity and cholesterol depositions, acts as an antioxidant and regulates matrix deposition.

Ultra structural changes were demonstrated microscopically in I/R rats. Our study shows that, after $1 \mathrm{~h}$ ischemia and $3 \mathrm{~h}$ reperfusion, there is accumulation of $\mathrm{Ca}^{2+}$ which leads to autophagosomes, reduction in the number of mitochondria and nuclear condensation. Pretreatment with amlodipine showed considerable prevention in the ultra structural alteration, including disruption of mitochondrial and nuclear fine structures. Both $\mathrm{Ca}^{2+}$ accumulation and oxidative stress increase the probability of changes in mitochondrial permeability and together with opening the transition pore in the mitochondria carry the signals for cell death (22). Amlodipine prevents cellular damage in the membrane probably by inhibiting the calcium channel of hepatocytes. A previous study reported that amlodipine reduced hepatic I/R injury by cytoprotective effects on parenchymal and non-parenchymal hepatocytes during both preservation and reperfusion (23). Other $\mathrm{Ca}^{2+}$ channel antagonists, verampril (24) and nimodipine, are also reported to have a protective role in hepatic I/ $\mathrm{R}$ induced injury. Thus, the present study, consistent with our previous study, provides evidence that amlodipine protects I/R rats from mitochondrial injury, giving an insight into the underlying mechanisms of the effects of amlodipine.

\section{CONCLUSIONS}

The present investigation suggests that the protective action of amlodipine, a calcium channel blocker, against the I/R induced liver injury in rats is due to its inhibitory action on $\mathrm{Ca}^{2+}$ influx into the mitochondria and probably to its antioxidant property. Additional studies are needed to determine whether there is a link between reductions in the I/ $\mathrm{R}$ induced injury liver markers as achieved with calcium antagonists and that obtained with oxygen radical scavengers.

Acknowledgements. - The authors are grateful to Dr. R. M. Dubey, Managing Director, IFTM and Dr. S. K. Srivastava, Principal Scientist, Indian Veterinary Research Institute, Izatnagar, India, for providing assistance and facility to carry out the research work. The authors also thank Sophisticated Instruments Facility, Department of Anatomy and Physiology, All India Institute of Medical Sciences (AIIMS), New Delhi, for TEM analysis. 
C. Pronobesh et al.: Protective role of the calcium channel blocker amlodipine against mitochondrial injury in ischemia and reperfusion injury of rat liver, Acta Pharm. 58 (2008) 421-428.

\section{REFERENCES}

1. A. Elimadi, R. Sapena, A. Settaf, H. Le Louet, J. Tillement and D. Morin, Attenuation of liver normothermic ischemia-reperfusion injury by preservation of mitochondrial functions with S-15176, a potent trimetazidine derivative, Biochem. Pharmacol. 62 (2001) 509-516; DOI: 10.1016/S006-2952 (01) 00676-1.

2. P. A. Detmers, S. K. Lo, S. K. E. Olsen-Egbert, A. Walz, M. Baggiolini and Z. A. Cohn, Neutrophil-activating protein 1 /interleukin 8 stimulates the binding activity of the leukocyte adhesion receptor CD11b/CD18 on human neutrophils, J. Exp. Med. 171 (1999) 1155-1162; DOI: 10.1084/ jem.171.4.1155.

3. A. L. Nieminen, A. K. Saylor, S. A. Tesfai, B. Herman and J. J. Lemasters, Contribution of the mitochondrial permeability transition to lethal injury after exposure of hepatocytes to $t$-butylhydroperoxide, Biochem. J. 307 (1995) 99-106.

4. J. H. Doroshow, Effect of anthracycline antibiotics on oxygen radical formation in rat heart, Cancer. Res. 43 (1983) 460-472.

5. O. Stepien, Y. Zhang, D. Zhu and P. Marche, Dual mechanism of action of amlodipine in human vascular smooth muscle cells, J. Hypertens. 20 (2002) 95-102.

6. R. Burges and D. Moisey, Unique pharmacologic properties of amlodipine, Am. J. Cardiol. 73 (1994) 2A-9A.

7. H. Hayashi, I. H. Chaudhury, M. Chemens and A. B. Bauue, Hepatic ischemia models to determine the effects of ATP $\mathrm{MgCl}_{2}$ treatment, J. Surgical Res. 40 (1988) 167-175; DOI: 10.1016/022-4804 (86) 90119-8.

8. D. Jonshon and H. Lardy, Isolation of Liver Kidney Mitochondria, in Methods in Enzymology (Ed. R. W. Estarbook), Vol. 10, Academic Press, London 1947, pp. 94-96.

9. J. A. Barltrop, T. C. Owen, A. H. Cory and J. G. Cory, 5-(3-Carboxymethoxyphenyl)-2-(4,5-dimethylthiazyl)-3-(4-sulfophenyl) tetrazolium, inner salt (MTS) and related analogs of 3-(4,5-dimethylthiozalyl)-2,5-diphenyltetrazolium bromide (MTT) reducing to purple water soluble forzamans as cell viability indicators, Bioorg. Med. Chem. Lett. 1 (1991) 611-614.

10. A. H. Mehler, A. Kornberg, S. Grisolia and S. Ochoa, The enzymatic mechanism of oxidation-reductions between malate or isocitrate or pyruvate, J. Biol. Chem. 174 (1948) 961-977.

11. E. C. Slater and W. D. Bonne, The effect of fluoride on the succinic oxidase system, Biochem. J. 52 (1952) 185-196.

12. S. Minakami, R. L. Ringler and T. P. Singer, Studies on the respiratory chain linked dihydrodiphospho pyridine nucleotide dehydrogenase, Assay of the enzyme in particulate and insoluble preparations, J. Biol. Chem. 237 (1962) 569-576.

13. W. H. Habig, M. J. Pabst and W. B. Jakoby, Glutathione-S-transferase. The first enzymatic step in mercapturic acid formation, J. Biol. Chem. 249 (1974) 7130-7139.

14. E. K. Hodgson and I. Fridovich, The interaction of bovine erythrocyte superoxide dismutase with hydrogen peroxide: chemiluminescences and peroxidation, Biochem. J. 14 (1975) 5399-5403.

15. S. Takahara, B. M. Hamilton, J. V. Nell, Y. Ogura and E. T. Nishimura, Hypocatalasemia, a new genetic carrier state, J. Clin. Invest. 29 (1960) 610-619.

16. H. Ohkawa, N. Ohishi and K. Yagi, Assay for lipid peroxides in animal tissues by thiobarbituric acid reaction, Anal. Biochem. 95 (1979) 351-358.

17. L. E. Solem, L. J. Heller and K. B. Wallace, Dose-dependent increase in sensitivity to calcium induced mitochondrial dysfunction and cardiomyocyte cell injury by doxorubicin, J. Mol Cell. Cardiol. 28 (1996) 1023-1032.

18. X. Xu, C. C. Chua, J. Kong, R. M. Kostrzewa, U. Kumaraguru, R. C. Hamdy and B. H. Chua, Necrostatin-1 protects against glutamate-induced glutathione depletion and caspase-independ- 
C. Pronobesh et al.: Protective role of the calcium channel blocker amlodipine against mitochondrial injury in ischemia and reperfusion injury of rat liver, Acta Pharm. 58 (2008) 421-428.

ent cell death in HT-22 cells, J. Neurochem. 103 (2007) 1132-1140; DOI: 10.1111/J1471-4159: 2007. 048841.x.

19. I. Cebalas-Picot, A. Nicole, M. Clement, J. M. Bourke and P. M. Signet, Age related changes in antioxidant enzymes and lipid peroxidation in brains of control and transgenic mice over expressing copper-zinc superoxide dismutase, Mut. Res. 275 (1992) 281-293.

20. M. Younes and O. Strubelt, The involvement of reactive oxygen species in hypoxic injury to rat liver, Res. Comm. Chem. Pathol. Pharmacol. 59 (1998) 369-381.

21. J. Wang, M. S. Wolin and T. H. Hintze, Chronic exercise enhances endothelium-mediated dilation of pericardial coronary artery in conscious dogs, Circulation Res. 73 (1993) 829-838.

22. B. K. Siesjo and F. Bengtsson, Calcium fluxes, calcium antagonists, and calcium-related pathology in brain ischemia, hypoglycemia, and spreading depression: a unifying hypothesis, J. Cerebral. Blood. Flow. Metab. 9 (1989) 127-140.

23. T. Piratvisuth, J. B. Dunne, R. Williams and J. M. Tredger, Amlodipine improves hepatic homodynamic and metabolic function in the isolated perfused rat liver after sequential cold and warm ischemia, Transplantation 60 (1995) 23-28.

24. R. E. Chavez-Cartaya, G. Pino DeSola, P. Ramirez-Romero, R. Y. Calne and N. V. Jamiesson, Ischemia and reperfusion injury of the rat liver: the role of nomodipine, J. Surg. Res. 60 (1996) 199-206.

\section{$S A \check{Z} E T A K$}

\section{Zaštitna uloga amlodipina, blokatora kalcijevih kanala, protiv oštećenja mitohondrija kod ishemičnih i reperfuzijskih ozljeda jetre štakora}

CHATTOPADHYAY PRONOBESH, AHER VAIBHAV, CHAUDHURY PALLAB i WAHI ARUN KUMAR

Akumulacija $\mathrm{Ca}^{2+}$ iona i njihovo nakupljanje u mitohondrijima uzrok je abnormalnosti u stanicama nakon ishemičnih i reperfuzijskih ozljeda. Cilj ovog rada bio je ispitati učinak amlodipina, blokatora kalcijevih kanala, na nakupljanje iona kalcija u mitohondrijima, antioksidativni status mitohondrija i na aktivnost enzima u dišnom lancu kod ishemičnih i reperfuzijskih (I/R) ozljeda jetre. Kod tih ozljeda smanjeno je djelovanje $(p<$ 0,05 ) enzima dišnog lanca (malat dehidrogenaze, sukcinat dehidrogenaze i NADH-dehidrogenaze), antioksidativnih enzima mitohondrija (glutation, superoksid dismutaze, katalaze), stupanj lipidne peroksidacije (LPO) i nakupljanje iona $\mathrm{Ca}^{2+}$.

Oštećenje mitohondrija potvrđeno je transmisijskom elektronskom mikroskopijom (TEM). Prethodna obrada s amlodipinom učinkovito sprječava promjenu aktivnosti enzima mitohondrija uzrokovanih I/R oštećenjima jetre. TEM potvrđuje uspostavljanje normalnih uvjeta u stanici i citoprotektivno djelovanje amlodipina. Na temelju rezultata naših istraživanja može se zaključiti da amlodipin zbog antioksidativnog djelovanja reducira oštećenje mitohondrija.

Ključne riječi: blokator kalcijevih kanala, amlodipin, ishemična i reperfuzijska ozljeda, oštećenje mitohondrija

Cellular and Microbiology Laboratory, College of Pharmacy, IFTM, Moradabad-24400, India

Birla Institute of Technology and Sciences, Pilani, India

National Biotechnology Center, Indian Veterinary Research Institute, Izatnagar, India 